\title{
Expression and clinical significance of IGF-I, IGFBP-3, and IGFBP-7 in serum and lung cancer tissues from patients with non-small cell lung cancer
}

\author{
This article was published in the following Dove Press journal: \\ OncoTargets and Therapy \\ 15 October 2013 \\ Number of times this article has been viewed
}

\author{
Zhigang Wang ${ }^{1,3}$ \\ Zheng Wang' \\ Zhu Liang ${ }^{3}$ \\ jikuan Liu $^{3}$ \\ Weicheng Shi ${ }^{3}$ \\ Peiru $\mathrm{Bai}^{3}$ \\ Xialu Lin $^{2}$ \\ Ruth Magaye ${ }^{2}$ \\ Jinshun Zhao ${ }^{2}$ \\ 'Jinan University, Guangzhou, \\ Guangdong, People's Republic of \\ China; ${ }^{2}$ Public Health Department of \\ Medical School, Zhejiang Provincial \\ Key Laboratory of Pathological and \\ Physiological Technology, Ningbo \\ University, Zhejiang, People's Republic \\ of China; ${ }^{3}$ The Affiliated Hospital \\ of Guangdong Medical College, \\ Zhanjiang, Guangdong, People's \\ Republic of China
}

\begin{abstract}
The expression and clinical significance of insulin-like growth factor 1 (IGF-1), insulin-like growth factor binding protein 3 (IGFBP-3), and insulin-like growth factor binding protein 7 (IGFBP-7) were investigated in serum and lung cancer tissues from 57 patients with non-small cell lung cancer (NSCLC). Lung cancer tissues at different pathologic stages (27 patients at stages I-II and 30 patients at stages III-IV), normal lung tissues from 17 patients with benign pulmonary disease, and serum samples from both lung cancer and benign pulmonary disease patients were collected during surgery. Enzyme-linked immunosorbent assay and avidinbiotin-peroxidase complex immunohistochemical staining were used to detect IGF-1, IGFBP-3, and IGFBP-7 expression in serum and tissues, respectively. The results show that expression of IGF-1 in lung cancer tissues and serum from NSCLC patients were significantly higher than in the control $(P<0.05)$. However, expression of IGFBP-3 and IGFBP-7 in cancer tissues and serum from NSCLC patients was significantly lower than in the control $(P<0.05)$. These results suggest that upregulation of IGF-1 and downregulation of IGFBP-3 and IGFBP-7 may be potential diagnostic biomarkers for NSCLC.
\end{abstract}

Keywords: insulin-like growth factor 1, insulin-like growth factor binding protein 3, insulin-like growth factor binding protein 7 , non-small cell lung cancer, diagnostic biomarkers

\section{Introduction}

Lung cancer is the second most common cancer in men and women and a leading cause of cancer-related deaths worldwide, with non-small cell lung cancer (NSCLC) representing approximately $85 \%$ of all cases. ${ }^{1}$ In addition, more than one half of affected patients have advanced metastasis with a poor prognosis. According to the International Agency for Research on Cancer of World Health Organization, lung cancer is the most common cancer in the world, with an estimated 1.6 million new cases in 2008, representing one in eight of all new cancers. It is also the most common form of cancer death in the world, comprising nearly one in five of all deaths from cancer. ${ }^{1}$ In the People's Republic of China, lung cancer has been the predominant type of cancer in males. ${ }^{2}$

Tumorigenesis can be induced by out-of-control cell proliferation and apoptosis or cell cycle dysfunction. In recent years, studies have demonstrated that, by binding to receptors, the insulin-like growth factor family (IGFs) can initiate the cell signal transduction pathway, promote cell mitosis, proliferation, and differentiation, and inhibit cell apoptosis. This, in turn, may play an important role in tumor occurrence
Correspondence: Jinshun Zhao Public Health Department of Medical School, Zhejiang Provincial Key Laboratory of Pathological and Physiological Technology, Ningbo University, Zhejiang, People's Republic of China

Tel +865748760 959l

Fax +86 57487608638

Email zhaojinshun@nbu.edu.cn 
and development. ${ }^{3}$ The biological effect of IGFs after binding to their receptors is regulated by a series of specific insulinlike growth factor binding proteins (IGFBPs). ${ }^{4}$ Research evidence shows that IGFs have mitogenic and antiapoptotic properties; they have been implicated in the development of lung cancer, and the effects of IGFs are modulated by IGFBPs. ${ }^{5,6}$ The rationale for measuring the fasting level of these proteins in peripheral blood is that, due to the anabolic nature of these proteins, fasting allows for normalization. To elucidate the relationship between IGF-1/IGFBPs and NSCLC, the expression of IGF-1, IGFBP-3, and IGFBP-7 in serum and lung tissues from NSCLC patients and controls were analyzed in this study.

\section{Materials and methods Materials}

Enzyme-linked immunosorbent assay (ELISA) kits for IGF-1 and IGFBP-3, a hematoxylin and eosin staining kit, Mayer's hematoxylin, and avidin-biotin complex stain were purchased from Wuhan Boster Biological Technology, Ltd (Wuhan, People's Republic of China). An IGFBP-7 ELISA kit was purchased from Shanghai Jintai Biological Technology, Ltd. (Shanghai, People's Republic of China). The ELISA reader was a MultiskanMK3, purchased from Shanghai Zhili Scientific Instrument Company Ltd., China (Shanghai, People's Republic of China). Rabbit anti-human IGF-1, IGFBP-3, and IGFBP-7 polyclonal antibodies were purchased from Santa Cruz Biotechnology (Santa Cruz, CA, USA). ELISA kits were purchased from Beijing Zhongshan Golden Bridge Biotechnology Co., Ltd. (Beijing, People's Republic of China).

\section{Methods}

\section{Selection of NSCLC and control cases}

Fifty-seven surgical inpatients with NSCLC (March through November 2010) from the department of thoracic surgery at the Affiliated Hospital of Guangdong Medical College (Zhanjiang, Guangdong, People's Republic of China) were selected as NSCLC cases, including 38 males and 19 females aged 27-84 years. According to the Union for International Cancer Control 2009 tumor, node, metastasis (TNM) staging standard for lung cancers and the World Health Organization histologic type classification standard for lung cancer, 19 cases were identified as squamous cell carcinoma and 38 cases as adenocarcinoma, with 27 patients being at stage I-II and 30 patients being at stage III-IV. During the same time period, seven male and ten female surgical inpatients aged 33-75 years with benign pulmonary disease were selected as the control group. These included three cases of bronchiectasis, five cases of inflammatory pseudotumor, five cases of tuberculosis ball, three cases of bronchial cyst, and one case of pulmonary sequestration. All NSCLC and control cases were diagnosed by pathologic examination (double-blind assessment by three pathologists) in the pathology department of the Affiliated Hospital of Guangdong Medical College. No case had preoperative chemotherapy or radiotherapy. Patients with diabetes or other metabolic disorders were excluded. In addition, human specimens collected for this study after surgical operations had been approved by the ethics committee of the Affiliated Hospital of Guangdong Medical College. All patients had provided their written consent to participate in this study.

\section{Serum collection and ELISA}

Before treatment, fasting peripheral venous blood $(5 \mathrm{~mL})$ was collected from all participants in the morning. Blood samples were kept at room temperature for 30 minutes, and then centrifuged at $150 \mathrm{~g}$ for 20 minutes. Supernatant serum was collected and stored at $-20^{\circ} \mathrm{C}$ until use. Serum IGF-1, IGFBP-3, and IGFBP-7 levels were then analyzed using ELISA according to the manufacturer's instructions.

\section{Lung tissue collection, avidin-biotin complex immunohistochemistry, and hematoxylin and eosin staining}

The tumorigenic tissues were harvested from the NSCLC patients during surgery. Normal lung tissues were harvested from the outer region of the lesions from control patients during surgery. All tissues were immediately fixed in $4 \%$ formalin for histopathologic examination. The formalin-fixed tissues were stored at $4^{\circ} \mathrm{C}$ until examination. Tissues were processed using standard histology laboratory techniques. Using a microtome, 3-4 $\mu \mathrm{m}$ sections were cut. These were then stained with avidin-biotin complex immunohistochemical stain following a standard staining protocol to detect expression of IGF-1, IGFBP-3, and IGFBP-7. Briefly, sections were treated with $3 \%$ peroxide in methanol for 15 minutes to block endogenous peroxidase activity, followed by overnight incubation with the primary antibody at $4^{\circ} \mathrm{C}$. Mouse primary monoclonal antibodies directed against IGF-I, IGFBP-3, and IGFBP-7 (1:100 dilution; Santa Cruz Biotechnology) were used in these experiments. After rinsing with phosphate-buffered saline, secondary biotinylated antisera were followed by the avidin-biotin complex (Wuhan Boster Biological Technology); the reaction was developed with 3-39-diaminobenzine-tetrahydrochloride and counterstained with Mayer's hematoxylin. IGF-I, IGFBP-3, and IGFBP-7 immunoreactivity was graded 
according to the relative immunostaining intensity (IGF-I, IGFBP-3, and IGFBP-7 stain intensity). Hematoxylin and eosin staining was conducted according to the manufacturer's instructions for indicating the pathology.

\section{Statistical analysis}

Statistical analyses were performed using Statistical Package for the Social Sciences version 17 software (SPSS Inc., Chicago, IL, USA). Two-samples mean comparison was analyzed by $t$-test. Multiple-sample mean comparison was analyzed by one-way analysis of variance. According to homogeneity variance results, the least squares difference test was used for data analyses when variance was equal, but Tamhane's $\mathrm{T} 2$ test was used when variance was unequal. The mutual relationship between two growth factors was analyzed by Pearson correlation analysis. The intragroup and intergroup expression difference detected by immunohistochemistry assay was analyzed by the rank-sum test. The correlation of two ranked data was analyzed by Spearman correlation analysis. The mean method was used to compare the means of measurement data among different groups. Eta and Eta square values were used to measure the correlation. Statistical significance was set at $P<0.05$.

\section{Results}

Comparison of serum IGF-I, IGFBP-3, and IGFBP-7 expression between

\section{NSCLC and controls}

The $t$-test showed that the concentration of IGF-1 in the serum from NSCLC cases $(159.24 \pm 44.74 \mu \mathrm{g} / \mathrm{L})$ was significantly higher than that from control cases $(128.79 \pm 25.40 \mu \mathrm{g} / \mathrm{L}$, $P=0.034)$. However, the concentration of IGFBP-3 in the serum from NSCLC cases $(1299.58 \pm 328.87 \mu \mathrm{g} / \mathrm{L})$ was significantly lower than that of control cases $(1611.56 \pm 405.08 \mu \mathrm{g} / \mathrm{L}$, $P=0.042$ ). The concentration of IGFBP-7 in serum from NSCLC cases $(32.51 \pm 14.05 \mathrm{ng} / \mathrm{L})$ was also significantly lower than that from control cases $(43.81 \pm 18.32 \mathrm{ng} / \mathrm{L}$, $P=0.026$, Figure 1).

\section{Stratification analysis of pathologic parameters and serum IGF-I, IGFBP-3, and IGFBP-7 concentrations in NSCLC cases}

Stratification analysis showed that concentrations of IGF-1, IGFBP-3, and IGFBP-7 in the serum of NSCLC cases had no significant $(P>0.05)$ association with the location of

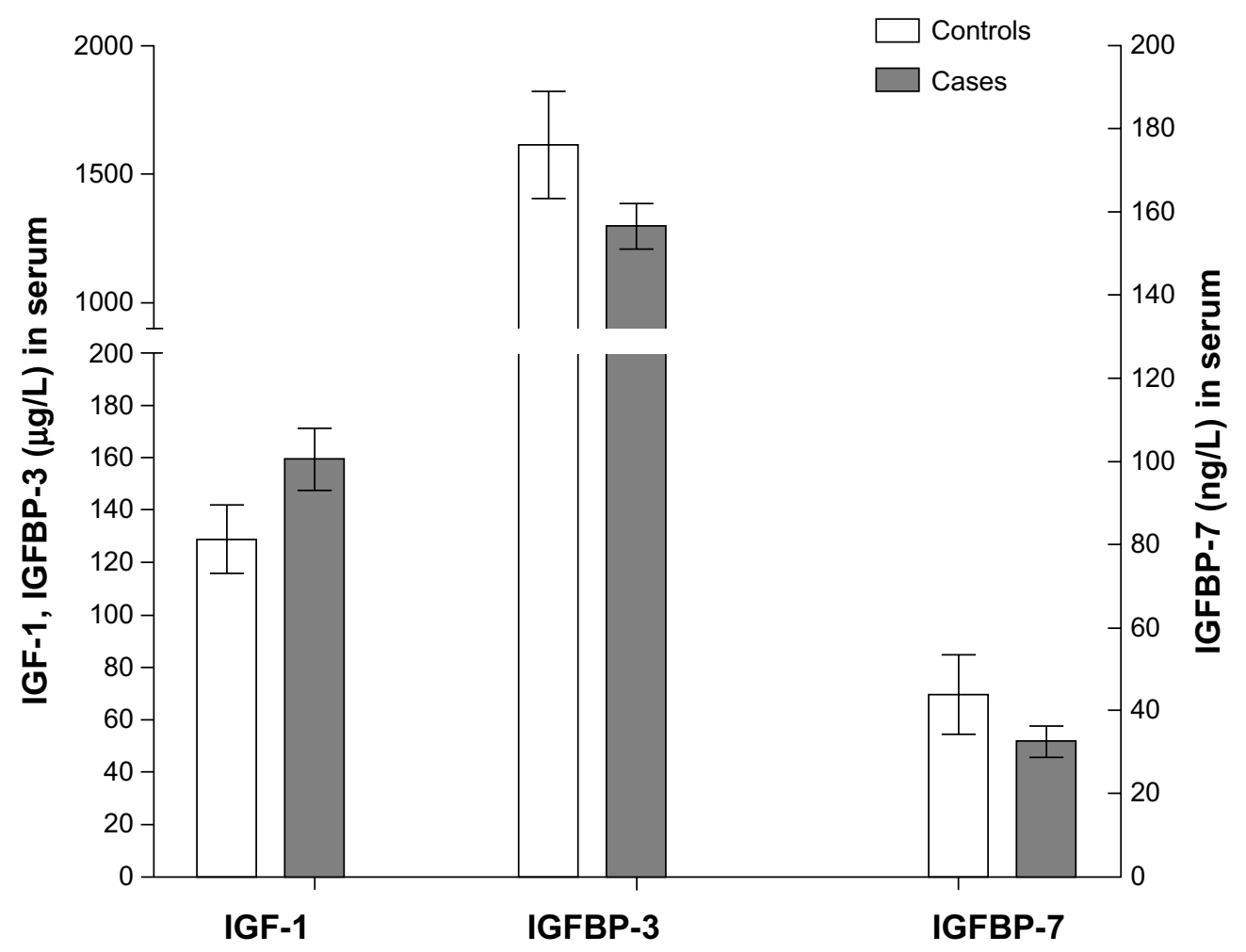

Figure I Comparison of serum IGF-I, IGFBP-3, and IGFBP-7 expression between NSCLC and control cases.

Abbreviations: IGF-I, insulin-like growth factor I; IGFBP-3, insulin-like growth factor binding protein 3; IGFBP-7, insulin-like growth factor binding protein 7; NSCLC, non-small cell lung cancer. 
NSCLC, diameter of the tumor, or pathologic grade or type, but was significantly $(P<0.05)$ associated with levels of lymph node metastasis, local invasion, distant metastasis, and TNM stage (Table 1).

\section{Correlation analysis of serum IGF-I and IGFBP-3 or IGFBP-7 concentrations in NSCLC cases}

Pearson correlation analysis showed that the concentrations of IGF-1 and IGFBP-3 in the serum of NSCLC cases had a significant negative correlation $(\mathrm{r}=-0.253, P=0.023)$, but there was no correlation between the concentrations of IGF-1 and IGFBP-7 in serum from NSCLC cases $(\mathrm{r}=-0.151$, $P=0.272)$.

\section{IGF-I, IGFBP-3, and IGFBP-7 expression in NSCLC tissue and normal control lung tissue}

The intensity of IGF-1, IGFBP-3, or IGFBP-7 expression in lung tissues from NSCLC cases was detected by avidin-biotin complex immunohistochemical staining (Figure 2). Pathology was shown by hematoxylin and eosin staining (Figure 3). IGF-1 expression in lung cancer tissues from NSCLC cases progressed from weakly positive to strongly positive, which was significantly stronger than that (mainly from negative to weak positive) in normal lung tissues from control cases
(40.57 versus 27.21, $P<0.05$ ). IGFBP-3 expression in lung cancer tissues from NSCLC cases progressed from negative to positive, and was significantly weaker than its expression in control cases (from positive to strong positive) (34.62 versus 47.15, $P<0.05$ ). IGFBP-7 expression in lung cancer tissues from NSCLC cases progressed from negative to positive, also significantly weaker than its expression in control cases (30.77 versus $40.40, P<0.05$, rank-sum test).

\section{IGF-I, IGFBP-3, and IGFBP-7 expression in lung cancer tissues and stratification analysis with pathologic parameters of NSCLC cases}

Stratification analysis showed that the intensity of IGF-1, IGFBP-3 and IGFBP-7 expression had no significant association $(P>0.05)$ with location of the lung tissue, tumor diameter, histologic type, or pathologic grade, but had a significant $(P<0.05)$ association with stage III-IV TNM, lymph node metastasis, and distance metastasis parameters (Table 2).

\section{Correlation analysis of intensity of IGF- I with IGFBP-3 or IGFBP-7 expression in lung tissues from NSCLC cases}

Spearman's rank correlation analysis showed that there was no significant correlation between the expression intensity of IGF-1 and IGFBP-3 $\left(r_{s}=0.224, \mathrm{n}=57, P=0.062\right)$. However,

Table I Stratification analysis on pathologic parameters and serum concentrations of IGF-I, IGFBP-3, and IGFBP-7 of NSCLC cases (mean \pm standard deviation)

\begin{tabular}{|c|c|c|c|c|c|c|c|c|}
\hline $\begin{array}{l}\text { Pathologic } \\
\text { parameters }\end{array}$ & Classification & $\begin{array}{l}\text { Case } \\
\text { number }\end{array}$ & $\begin{array}{l}\text { IGF-I } \\
(\mu \mathrm{g} / \mathrm{L})\end{array}$ & $P$ & $\begin{array}{l}\text { IGFBP-3 } \\
(\mu \mathrm{g} / \mathrm{L})\end{array}$ & $P$ & $\begin{array}{l}\text { IGFBP-7 } \\
\text { (ng/L) }\end{array}$ & $P$ \\
\hline \multirow[t]{2}{*}{ Location } & Central type & 17 & $157.36 \pm 26.70$ & 0.454 & $|3| 4.2 \mid \pm 388.22$ & 0.751 & $39.94 \pm 16.43$ & 0.307 \\
\hline & peripheral type & 40 & $|64.92 \pm 37.4|$ & & $1283.37 \pm 309.89$ & & $28.86 \pm 18.45$ & \\
\hline Tumor & $\mathrm{d} \leq 3 \mathrm{~cm}$ & 18 & $157.36 \pm 36.57$ & 0.363 & $1347.88 \pm 373.77$ & 0.675 & $29.93 \pm 10.08$ & 0.367 \\
\hline \multirow[t]{2}{*}{ diameter } & $3 \mathrm{~cm}<\mathrm{d} \leq 7 \mathrm{~cm}$ & 34 & $167.89 \pm 32.98$ & & $1267.65 \pm 308.93$ & & $37.72 \pm 25.81$ & \\
\hline & $\mathrm{d}>7 \mathrm{~cm}$ & 5 & $148.40 \pm 36.59$ & & $1246.79 \pm 357.19$ & & $42.37 \pm 20.67$ & \\
\hline Pathologic & High differentiation & 11 & $158.60 \pm 30.16$ & 0.739 & $|43| .36 \pm 382.3 \mid$ & 0.143 & $32.63 \pm 12.66$ & 0.537 \\
\hline \multirow[t]{2}{*}{ grade } & Middle differentiation & 19 & $160.06 \pm 36.10$ & & $1316.87 \pm 268.95$ & & $35.29 \pm 22.11$ & \\
\hline & Low differentiation & 27 & $166.7 \mid \pm 36.04$ & & $1206.49 \pm 338.97$ & & $41.86 \pm 31.91$ & \\
\hline Lymph node & No & 25 & $|48.69 \pm 26.6|$ & 0.023 & $|488.95 \pm 340.8|$ & 0.001 & $39.98 \pm 20.09$ & 0.043 \\
\hline metastasis & Yes & 32 & $\mid 70.23 \pm 36.21$ & & $1240.47 \pm 319.50$ & & $30.16 \pm 14.36$ & \\
\hline \multirow[t]{2}{*}{ Local invasion } & $\mathrm{TI}-\mathrm{T} 2$ & 39 & $153.29 \pm 32.32$ & 0.001 & $1372.42 \pm 335.27$ & 0.004 & $42.45 \pm 16.02$ & 0.032 \\
\hline & T3-T4 & 18 & $184.76 \pm 29.73$ & & $1104.67 \pm 240.96$ & & $31.25 \pm 13.70$ & \\
\hline Distant & No & 43 & $151.74 \pm 28.19$ & 0.002 & $1375.63 \pm 16.8 \mid$ & 0.001 & $49.25 \pm 34.06$ & 0.006 \\
\hline metastasis & Yes & 14 & $193.27 \pm 32.78$ & & $1060.08 \pm 260.84$ & & $31.05 \pm 19.19$ & \\
\hline Pathologic & Squamous carcinoma & 18 & $154.72 \pm 28.27$ & 0.222 & $1288.63 \pm 349.29$ & 0.950 & $37.53 \pm 24.81$ & 0.664 \\
\hline type & Adenocarcinoma & 39 & $166.65 \pm 36.56$ & & $1294.54 \pm 327.63$ & & $34.8 I \pm 20.4 I$ & \\
\hline \multirow[t]{2}{*}{ TNM stage } & I-II & 26 & $|5| .21 \pm 29.95$ & 0.016 & $|4| 2.69 \pm 327.87$ & 0.008 & $39.31 \pm 20.80$ & 0.034 \\
\hline & III-IV & 31 & $172.98 \pm 35.54$ & & $1184.45 \pm 301.30$ & & $28.34 \pm 16.37$ & \\
\hline
\end{tabular}

Abbreviations: TNM, tumor, node, metastasis; NSCLC, non-small cell lung cancer; IGF-I, insulin-like growth factor I; IGFBP-3, insulin-like growth factor binding protein 3; IGFBP-7, insulin-like growth factor binding protein 7. 

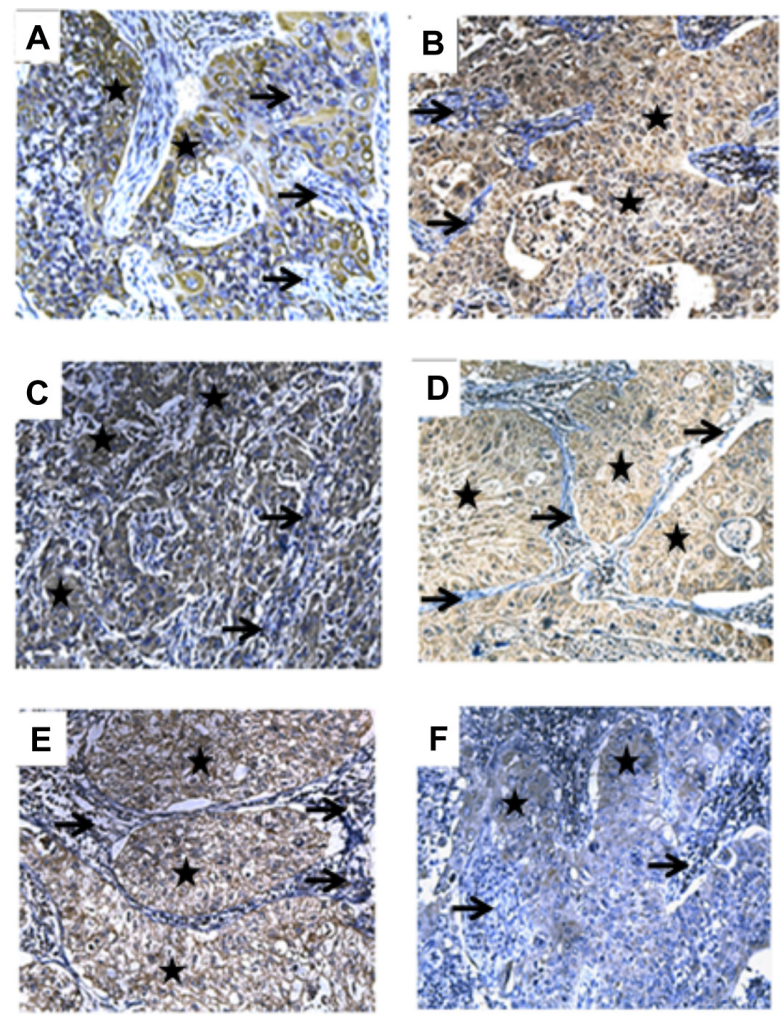

Figure 2 Intensity of IGF-I, IGFBP-3, or IGFBP-7 expression in lung tissues at different stages of squamous carcinoma of the lung. (A) IGF-I expression in stage la squamous carcinoma of the lung, slightly positive (yellow-brown staining). (B) IGF-I expression in stage llb squamous carcinoma of the lung, strongly positive. (C) IGFBP-3 expression in stage la lung squamous carcinoma, strong positive. (D) Expression of IGFBP-3 in Ilb stage squamous carcinoma of the lung, slightly positive. (E) IGFBP-7 expression in stage la squamous carcinoma of the lung, strongly positive. (F) IGFBP-7 expression in stage llb squamous carcinoma of the lung, slightly positive. All figures were captured under the microscope at 200× magnification. ${ }^{\star}$ Lung tumor tissue areas; $\rightarrow$ normal lung tissue areas.

Abbreviations: IGF-I, insulin-like growth factor I; IGFBP-3, insulin-like growth factor binding protein 3; IGFBP-7, insulin-like growth factor binding protein 7.

there was a significant negative correlation between the expression intensities of IGF-1 and IGFBP-7 $\left(r_{s}=-0.437\right.$, $\mathrm{n}=57, P=0.001)$.

\section{Association of IGF-I, IGFBP-3, or IGFBP-7 concentrations in serum and expression intensity in lung tissues from NSCLC cases}

Serum IGF-1 concentrations were significantly different $(P<0.05)$, with a positive correlation $($ Eta $=0.369)$ at different levels of IGF-1 expression intensity in lung cancer tissues from NSCLC cases shown by the measures of association test. Serum IGFBP-3 concentrations showed no significant differences $(P>0.05)$, with a slight positive correlation $($ Eta $=0.079)$ at different levels of IGFBP-3 expression intensity in lung tissues from NSCLC cases. Serum IGFBP-7 concentrations showed no significant differences $(P>0.05)$, with a slight positive correlation $(\mathrm{Eta}=0.144)$ at different
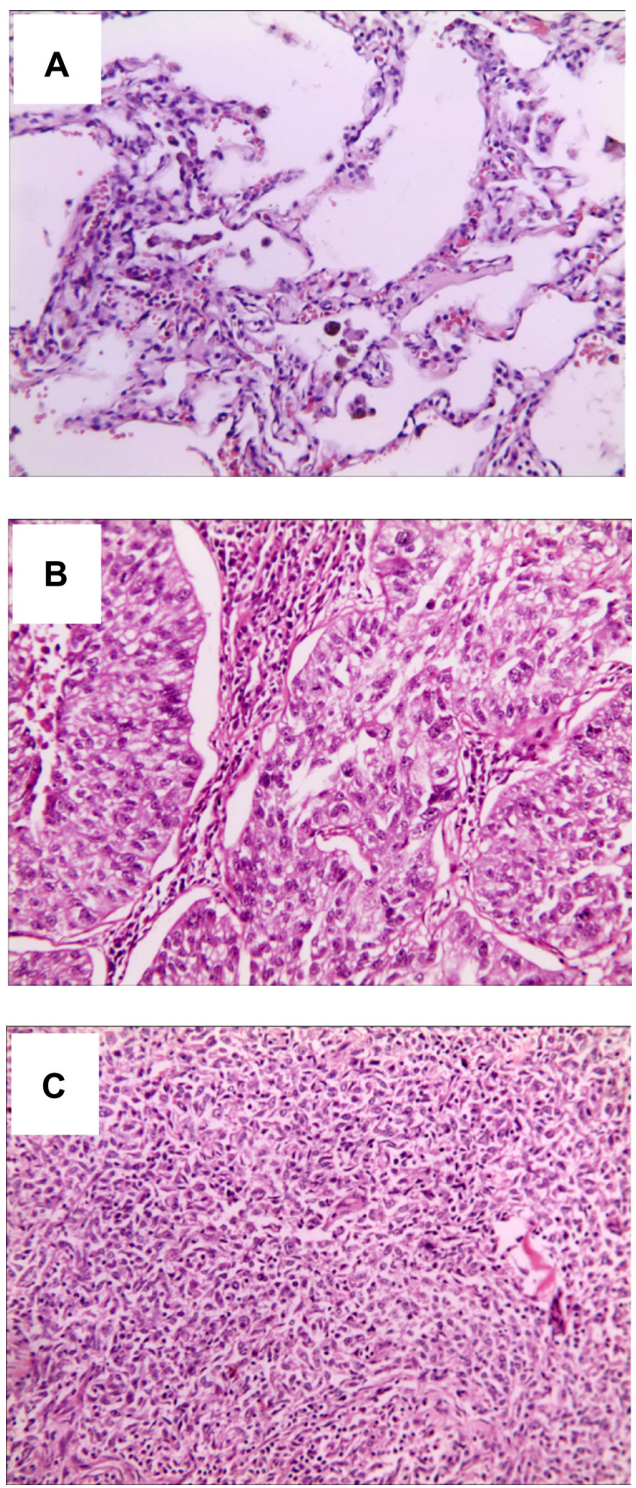

Figure 3 Pathology of normal lung tissue and stage la and llb of squamous carcinoma of the lung. (A) Normal lung tissue, (B) stage la squamous carcinoma of the lung, and (C) stage Ilb squamous carcinoma lung tissue. All figures were captured under the microscope at $200 \times$ magnification.

levels of IGFBP-7 expression intensity in lung tissues from NSCLC cases.

\section{Discussion}

IGF-1, a growth hormone, was first identified by Salmon and Daughaday in 1957, and since then the function of growth hormone-IGF in regulating cell growth and apoptosis has been widely investigated. ${ }^{3}$ IGF-1 is produced primarily by the liver as an endocrine hormone as well as in target tissues in a paracrine/autocrine fashion. ${ }^{7}$ Its primary action is mediated by binding to its receptor, the insulin-like growth factor 1 receptor (IGF-1R), present on many cell types in many tissues. IGF-1R then stimulates systemic body growth, and has growth-promoting effects on almost every cell in 
Table 2 Stratification analysis on association of expression of IGF-I, IGFBP-3, and IGFBP-7 in lung tissues and its pathologic parameters in NSCLC cases

\begin{tabular}{|c|c|c|c|c|c|c|c|c|}
\hline $\begin{array}{l}\text { Pathologic } \\
\text { parameters }\end{array}$ & Classification & $\begin{array}{l}\text { Case } \\
\text { number }\end{array}$ & $\begin{array}{l}\text { IGF-I } \\
\text { average rank }\end{array}$ & $P$ & $\begin{array}{l}\text { IGFBP-3 } \\
\text { average rank }\end{array}$ & $P$ & $\begin{array}{l}\text { IGFBP-7 } \\
\text { average rank }\end{array}$ & $P$ \\
\hline \multirow{2}{*}{ Location } & Central type & 17 & 27.95 & 0.435 & 26.95 & 0.121 & 32.94 & 0.112 \\
\hline & Peripheral type & 40 & 31.47 & & 33.82 & & 27.33 & \\
\hline \multirow[t]{3}{*}{ Tumor diameter } & $\leq 3 \mathrm{~cm}$ & 18 & 24.39 & 0.253 & 33.26 & 0.131 & 25.97 & 0.181 \\
\hline & $3 \mathrm{~cm}<\mathrm{d} \leq 7 \mathrm{~cm}$ & 34 & 30.80 & & 25.55 & & 28.93 & \\
\hline & $\mathrm{d}>7 \mathrm{~cm}$ & 5 & 34.60 & & 35.60 & & 40.40 & \\
\hline \multirow[t]{3}{*}{ Pathologic grade } & High differentiation & II & 20.25 & 0.071 & 27.58 & 0.857 & 24.09 & 0.707 \\
\hline & Middle differentiation & 19 & 29.53 & & 28.30 & & 29.63 & \\
\hline & Low differentiation & 27 & 32.78 & & 30.24 & & 30.56 & \\
\hline Lymph node & No & 25 & 23.10 & 0.036 & 37.85 & 0.001 & 32.16 & 0.011 \\
\hline metastasis & Yes & 32 & 32.19 & & 24.22 & & 26.53 & \\
\hline \multirow[t]{2}{*}{ Local invasion } & $\mathrm{TI}-\mathrm{T} 2$ & 39 & 25.94 & 0.025 & 37.24 & 0.009 & 32.83 & 0.039 \\
\hline & T3-T4 & 18 & 34.30 & & 25.50 & & 28.62 & \\
\hline \multirow[t]{2}{*}{ Distant metastasis } & No & 43 & 26.36 & 0.032 & 32.60 & 0.003 & 30.77 & 0.014 \\
\hline & Yes & 14 & 36.40 & & 18.93 & & 23.57 & \\
\hline \multirow[t]{2}{*}{ Pathologic type } & Squamous carcinoma & 18 & 28.82 & 0.950 & 32.68 & 0.199 & 32.42 & 0.219 \\
\hline & Adenocarcinoma & 39 & 29.09 & & 27.16 & & 27.42 & \\
\hline \multirow[t]{2}{*}{ TNM stage } & I-II & 26 & 24.07 & 0.024 & 33.96 & 0.020 & 31.92 & 0.038 \\
\hline & III-IV & 31 & 33.43 & & 24.53 & & 26.55 & \\
\hline
\end{tabular}

Abbreviations: TNM, tumor, node, metastasis; NSCLC, non-small cell lung cancer; IGF-I, insulin-like growth factor I; IGFBP-3, insulin-like growth factor binding protein 3; IGFBP-7, insulin-like growth factor binding protein 7.

the human body. In addition to its insulin-like effects, IGF$1 \mathrm{R}$ can also regulate cell growth and development. IGF-1R seems to have assumed an important role, especially in cancer biology. ${ }^{8}$ In recent years, studies have shown that IGF-1 can enhance expression and activity of the latent form of urokinase-type plasminogen activator, matrix metalloproteinase-2, matrix metalloproteinase- 9 , and promotes cancer cell invasion. ${ }^{910}$ The IGFBPs are a family of homologous proteins that have coevolved with the IGFs. ${ }^{11}$ Normally, the amount of IGFBP-3 in the serum is very low, but it can be increased under certain physiologic or pathologic conditions like pregnancy, surgery, or malignancy. ${ }^{12} \mathrm{~A}$ study by $\mathrm{Oh}$ et al showed that IGFBP-3 can effectively prevent urokinase-type plasminogen activator and matrix metalloproteinase- 9 from stimulating the invasion pathways, and ultimately reduce metastasis of lung cancer cells. ${ }^{13}$ Chen et al ${ }^{14}$ investigated 138 patients with lung cancer and 20 cases of normal lung tissue by immunohistochemistry and confirmed that insulin-like growth factor binding protein-related protein 1 (IGFBP-rP1) had high expression levels in normal tissues and low expression levels in cancer tissues. Moreover, by polymerase chain reaction sequencing and in nude mice experiments, they found that IGFBP-rP1 could inhibit tumor growth rate, increase the number of apoptotic cells, and activate expression of caspase-3. ${ }^{14}$ IGFBP-rPl plays a role as a tumor suppressor in human lung cancer by downregulating the methylation of DNA. ${ }^{14}$
The spread of cancer involves multiple steps, including cell adhesion to extracellular matrix-specific glycoprotein, prevention of the degraded extracellular matrix composition migrating out of the blood vessels via tumor-related protein, and local invasion. ${ }^{15,16}$ Our results show that IGF-1 expression in NSCLC cases was significantly higher than that in the benign lung lesion cases, and expression was increased as malignant lung cancer progression occurred, suggesting that IGF-1 has a greater capacity for promoting mitosis in lung cancer. ${ }^{17}$ The high level of IGF-1 expression may play an important role in the development of lung cancer, promoting proliferation of cancer cells and inhibiting their apoptosis. In this study, we also found that, in cases with lymph node metastasis, distant metastasis, invasion of the chest wall, pericardium, or great vessels, or at TNM stages III-IV, the concentrations or expression of IGF-1 in serum or lung cancer tissues was significantly higher than in patients without lymph node metastasis, distant metastasis, local invasion, invasion of the visceral pleura, or at TNM stage I-II. This result suggests that IGF-1 may be involved in local invasion and distant metastasis of lung cancers. Therefore, the serum IGF-1 concentration and intensity of its expression in lung cancer tissues may have clinical significance in early diagnosis and prediction of NSCLC. A new molecular target therapy that regulates the level of IGF-1 expression or blocks IGF-1 from binding with its cell surface receptor might be useful in the treatment of NSCLC. 
In addition, we found that the concentration of IGFBP-3 in serum in NSCLC cases was significantly lower than in controls, and there were a negative correlation between the concentrations of IGF-1 and IGFBP-3 in serum. Under circumstances of lymph node metastasis, distant metastasis, invasion of the chest wall, pericardium, or great vessels, or TNM stage III-IV, the concentration or expression of IGFBP-3 in serum and lung cancer tissue was significantly lower than that in patients without lymph node metastasis, distant metastasis, local invasion or only invasion of the visceral pleura, or TNM stage I-II. These results suggest that regulation of IGFBP-3 by IGF-1 may be through binding with IGF-1 and then inhibiting its effect of promoting differentiation and proliferation of tumor cells. In an in vitro experiment, Alami et al ${ }^{18}$ found that recombinant human IGFBP-3 could inhibit proliferation of M-3LL lung cancer cells in a dose-dependent manner, and could also significantly inhibit tumor growth after M-3LL cell transplantation in mice. Although no correlation between concentrations of IGF-1 and IGFBP-7 in the serum from NSCLC cases was found in this study, the expression of IGFBP-7 decreased as the lung cancer progressed, suggesting that IGFBP-7 may also be a lung cancer inhibitor.

In conclusion, our results suggest that expression of IGF1, IGFBP-3, and IGFBP-7 in serum and lung tissues may play an important role in the development of lung cancer. Detection of IGF-1, IGFBP-3, and IGFBP-7 in the peripheral serum could be significant in risk assessment of lung cancer patients, early prediction of the presence or absence of potential lymph node metastasis and distant metastasis, and thereby guide clinical treatment. Upregulation of IGF-1 and downregulation of IGFBP-3 and IGFBP-7 may be potential diagnostic biomarkers for NSCLC. To reduce the circulating and local expression of IGF-1 and enhance IGFBP-3 and IGFBP-7 levels in the body may become one of the targets of lung cancer treatment in future.

\section{Acknowledgments}

This work was partly supported by grants from the Zhanjiang Scientific Project (2010004), Guangdong Scientific Project (2011B080701039), the National Nature Science Foundation of China (81273111), the Ningbo Scientific Project (2012C5019), and the KC Wong Magna Fund in Ningbo University.

\section{Disclosure}

The authors report no conflicting interests in this work.

\section{References}

1. Ferlay J, Shin HR, Bray F, Forman D, Mathers C, Parkin DM. Cancer Incidence and Mortality Worldwide: IARC CancerBase No 10. Lyon, France: International Agency for Research on Cancer; 2010. Available from: http://globocan.iarc.fr. Accessed August 24, 2013.

2. Wang YC, Wei LJ, Liu JT, Li SX, Wang QS. Comparison of cancer incidence between China and the USA. Cancer Biol Med. 2012;9(2): $128-132$.

3. Grimberg A, Cohen P. Role of insulin-like growth factors and their binding proteins in growth control and carcinogenesis. J Cell Physiol. 2000;183(1):1-9.

4. Hermani A, Shukla A, Medunjanin S, Werner H, Mayer D. Insulin-like growth factor binding protein-4 and -5 modulate ligand-dependent estrogen receptor-alpha activation in breast cancer cells in an IGFindependent manner. Cell Signal. 2013;25(6):1395-1402.

5. Lee HY, Chun KH, Liu B, et al. Insulin-like growth factor binding protein-3 inhibits the growth of non-small cell lung cancer. Cancer Res. 2002;62(12):3530-3537.

6. Sueoka N, Lee HY, Wiehle S, et al. Insulin-like growth factor binding protein-6 activates programmed cell death in non-small cell lung cancer cells. Oncogene. 2000;19(38):4432-4436.

7. Hausman DB, DiGirolamo M, Bartness TJ, Hausman GJ, Martin RJ. The biology of white adipocyte proliferation. Obes Rev. 2001;2(4): 239-254.

8. Baserga R, Peruzzi F, Reiss K. The IGF-1 receptor in cancer biology. Int J Cancer. 2003;107(6):873-877.

9. Dunn SE, Torres JV, Oh JS, Cykert DM, Barrett JC. Up-regulation of urokinase-type plasminogen activator by insulin-like growth factor-I depends upon phosphatidylinositol-3 kinase and mitogen-activated protein kinase kinase. Cancer Res. 2001;61(4):1367-1374.

10. Bredin CG, Liu Z, Klominek J. Growth factor-enhanced expression and activity of matrix metalloproteases in human non-small cell lung cancer cell lines. Anticancer Res. 2003;23(6C):4877-4884.

11. Kelley KM, Oh Y, Gargosky SE, et al. Insulin-like growth factorbinding proteins (IGFBPs) and their regulatory dynamics. Int J Biochem Cell Biol. 1996;28(6):619-637.

12. Baciuchka M, Remacle-Bonnet M, Garrouste F, Favre R, Sastre B, Pommier G. Insulin-like growth factor (IGF)-binding protein-3 (IGFBP-3) proteolysis in patients with colorectal cancer: possible association with the metastatic potential of the tumor. Int $J$ Cancer. 1998;79(5):460-467.

13. Oh SH, Lee OH, Schroeder CP, et al. Antimetastatic activity of insulin-like growth factor binding protein-3 in lung cancer is mediated by insulin-like growth factor-independent urokinase-type plasminogen activator inhibition. Mol Cancer Ther. 2006;5(11): 2685-2695.

14. Chen Y, Pacyna-Gengelbach M, Ye F, et al. Insulin-like growth factor binding protein-related protein 1 (IGFBP-rP1) has potential tumoursuppressive activity in human lung cancer. J Pathol. 2007;211(4): 431-438.

15. Engers R, Gabbert HE. Mechanisms of tumor metastasis: cell biological aspects and clinical implications. J Cancer Res Clin Oncol. 2000;126(12):682-692.

16. Reuning U, Magdolen V, Hapke S, Schmitt M. Molecular and functional interdependence of the urokinase-type plasminogen activator system with integrins. Biol Chem. 2003;384(8):1119-1131.

17. Furstenberger G, Senn HJ. Insulin-like growth factors and cancer. Lancet Oncol. 2002;3(5):298-302.

18. Alami N, Page V, Yu Q, et al. Recombinant human insulin-like growth factor-binding protein 3 inhibits tumor growth and targets the Akt pathway in lung and colon cancer models. Growth Horm IGF Res. 2008;18(6):487-496. 


\section{Publish your work in this journal}

OncoTargets and Therapy is an international, peer-reviewed, open access journal focusing on the pathological basis of all cancers, potential targets for therapy and treatment protocols employed to improve the management of cancer patients. The journal also focuses on the impact of management programs and new therapeutic agents and protocols on

patient perspectives such as quality of life, adherence and satisfaction. The manuscript management system is completely online and includes a very quick and fair peer-review system, which is all easy to use. Visit http://www.dovepress.com/testimonials.php to read real quotes from published authors.

Submit your manuscript here: http://www.dovepress.com/oncotargets-and-therapy-journal 